\title{
The efficiency of electrocardioversion-induced rhythm restoration performed in University Clinical Center Tuzla
}

\section{-Emir Becirovic*, (DAmmar Brkic, CDsad Brkic, DAmira Kusljugic, DEdita Sijercic, - $C$ Hazim Tulumovic, DDenis Mrsic, DDaniela Loncar}

University Clinical Center Tuzla, Tuzla, Bosnia and Herzegovina
RECEIVED:

October 26, 2018

ACCEPTED:

November 5, 2018

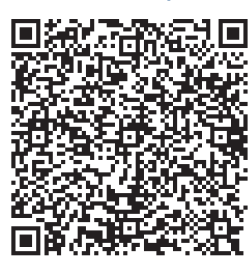

KEYWORDS: atrial fibrillation, anticoagulant therapy, elective electrocardioversion. CITATION: Cardiol Croat. 2018;13(11-12):319. | https://doi.org/10.15836/ccar2018.319

*ADDRESS FOR CORRESPONDENCE: Emir Becirovic, JZU Univerzitetski klinički centar Tuzla, Ibre Pasica, BA-75000 Tuzla, Bosnia and Herzegovina. / Phone: +387-61-876152 / E-mail: becirovic.emil@live.com

ORCID: Emir Becirovic, http://orcid.org/0000-0002-4134-987X • Ammar Brkic, http://orcid.org/0000-0002-5436-3670 Esad Brkic, http://orcid.org/0000-0002-7784-328X • Amira Kusljugic, http://orcid.org/0000-0003-4537-4615 Edita Sijercic, http://orcid.org/0000-0001-5926-7226 • Hazim Tulumovic, http://orcid.org/0000-0002-0662-5576 Denis Mrsic, http://orcid.org/0000-0002-6736-9561 • Daniela Loncar, http://orcid.org/0000-0001-8186-1766

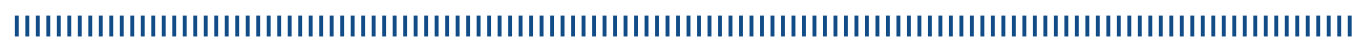

Background: Atrial fibrillation, as the most common type of arrhythmia, affects 1-2\% of general population. Currently more than 6 million Europeans are experiencing this condition, since the average age of population is increasing, and it is expected that this number will rise in next 50 years by $250 \%$. Atrial fibrillation usually leaves lasting consequences on patients overall health. Preventing them is the main therapeutic goal. ${ }^{1-3}$ The main objective of this study was to inspect the efficiency of sinus rhythm restoration by means of electrocardioversion. Hemodynamically unstable patients (suffering from angina pectoris or hypertension), unresponsive to resuscitation, are subjected to emergency electrocardioversion. On the other hand, stable patients should undergo electrocardioversion procedure after three week long anticoagulant treatment with warfarin. Patients should continue taking warfarin for four weeks after the procedure in sake of blood clot forming prevention.

Case report: From January 2017 to September 2018, 58 elective cardioversion cases were done by the Intensive Therapy Unit of the University Clinical Center of Tuzla, 12 of which were atrial flutter patients, while 40 patients had atrial fibrillation. From those 40 cases of atrial fibrillation, 6 patients underwent two cardioversion treatments using $150 \mathrm{~J}$ of energy, followed by single $200 \mathrm{~J}$ treatment. In 50 cases patients were brought back to sinus rhythm straightaway after the first treatment.

Conclusion: Although efficiency rate is high (96\%), qualified personnel and suitable equipment remain the most important requirements for successful and safe electrocardioversion. In long-term fibrillation, success rate of electrocardioversion and sinus rhythm perseverance decreases over time, especially if it lasts for more than a year. In that case, monitoring of the heart rate and anticoagulative therapy should be minded.

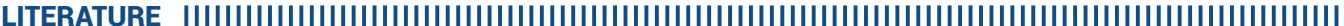

1. Hindricks G, Willems S, Kautzner J, De Chillou C, Wiedemann M, Schepel S, et al; EuroFlutter Investigators. Effect of electroanatomically guided versus conventional catheter ablation of typical atrial flutter on the fluoroscopy time and resource use: a prospective randomized multicenter study. J Cardiovasc Electrophysiol. 2009 Jul;20(7):734-40. https://doi.org/10.1111/j.1540-8167.2009.01439.x

2. Savelieva I, Camm J. Update on atrial fibrillation: part I. Clin Cardiol. 2008 Feb;31(2):55-62. https://doi.org/10.1002/clc.20138

3. Weerasooriya R, Jais P, Le Heuzey JY, Scaveé C, Choi KJ, Macle L, et al. Cost analysis of catheter ablation for paroxysmal atrial fibrillation. Pacing Clin Electrophysiol. 2003 Jan;26(1 Pt 2):292-4. https://doi.org/10.1046/j.1460-9592.2003.00035.x 